\title{
Ultimum Remedium dalam Bidang Lingkungan Hidup
}

\author{
Lidya Suryani Widayati \\ Peneliti Madya Bidang Hukum pada Pusat Pengkajian, Pengolahan \\ Data, dan Informasi (P3DI) Sekretariat Jenderal DPR RI \\ Jl. Jenderal Gatot Subroto Jakarta 10270. Gedung Nusantara III. \\ lidyadhi@yahoo.com, lidya.widayati@dpr.go.id
}

\begin{abstract}
The law enforcement in environmental field can be done both through administrative/civil law and criminal law. In recent developments, the law enforcement in environmental field tends to shift towards premium remedium. This research aims at analyzing principle feasibility of ultimum remedium in the environmental field through normative law research or literary law research by applying juridicial approach. This research concludes that criminal law enforcement in environmental field case by still referring to the principle of ultimum remedium is no longer worth to be held as the environmental cases lead to some harmful impacts on the nature and people's life.
\end{abstract}

Keywords: Ultimum remedium, environment

\begin{abstract}
Abstrak
Dalam penegakan hukum di bidang lingkungan hidup, selain penyelesaian melalui hukum administratif juga melalui penerapan hukum pidana. Dalam perkembangan terakhir penegakan hukum di bidang lingkungan lebih mendekati ke arah premium remedium. Penelitian ini bertujuan untuk menganalisis kelayakan asas ultimum remedium di bidang lingkungan hidup melalui penelitian hukum normatif atau penelitian hukum kepustakaan dengan menggunakan pendekatan yuridis. Penelitian ini menyimpulkan bahwa penegakan hukum pidana dalam permasalahan lingkungan hidup yaitu dengan tetap memperhatikan asas ultimum remedium sudah tidak layak lagi untuk dipertahankan yaitu ketika permasalahan lingkungan hidup telah menimbulkan dampak negatif terhadap kehidupan dan jiwa manusia.
\end{abstract}

Kata kunci: Ultimum remedium, lingkungan hidup 


\section{Pendahuluan}

Penjelasan umum atas UU No. 32 Tahun 2009 tentang Perlindungan dan Pengelolaan Lingkungan Hidup (UU PPLH) menyatakan bahwa penegakan hukum pidana lingkungan tetap memperhatikan asas ultimum remedium yang mewajibkan penerapan penegakan hukum pidana sebagai upaya terakhir setelah penerapan penegakan hukum administratif dianggap tidak berhasil. Namun, asas ultimum remedium tersebut hanya berlaku bagi tindak pidana formil tertentu, yaitu pemidanaan terhadap pelanggaran baku mutu air limbah, emisi, dan gangguan, sebagaimana diatur dalam Pasal 100 UU PPLH. Dengan demikian, untuk tindak pidana lainnya (selain dalam Pasal 100) tidak berlaku asas ultimum remedium. Artinya, penegakan hukum terhadap tindak pidana selain dalam Pasal 100 berlaku asas premium remedium (mendahulukan penegakan hukum melalui sarana hukum pidana).

Berbeda dengan undang-undang sebelumnya, yaitu UU No. 23 Tahun 1997 tentang Pengelolaan Lingkungan Hidup. Penjelasan umum UU No. 23 Tahun 1997 menyatakan bahwa sebagai penunjang hukum administratif, berlakunya ketentuan hukum pidana tetap memperhatikan asas subsidiaritas, yaitu bahwa hukum pidana hendaknya didayagunakan apabila sanksi bidang hukum lain, seperti sanksi administratif dan sanksi perdata, dan alternatif penyelesaian sengketa lingkungan hidup tidak efektif dan/atau tingkat kesalahan pelaku relatif berat dan/atau akibat perbuatannya relatif besar dan/atau perbuatannya menimbulkan keresahan masyarakat. Dengan demikian, penegakan hukum terhadap tindak pidana di bidang lingkungan hidup berdasarkan undang-undang ini menganut asas ultimum remedium.

Sebelum berlakunya UU No. 23 Tahun 1997 terdapat UU No. 4 Tahun 1982 tentang Ketentuan-Ketentuan Pokok Pengelolaan Lingkungan Hidup. Dalam UU No. 4 Tahun 1982 terdapat pengaturan mengenai ganti kerugian dan biaya pemulihan (yang dapat dimasukan sebagai sanksi administratif) dan sanksi pidana. Namun, undang-undang ini tidak secara tegas menentukan mengenai subsidiaritas sanksi pidana atas sanksi administratif. 
Terdapat beberapa UU sektoral yang terkait dengan bidang lingkungan hidup memuat tentang ketentuan pidana, ${ }^{1}$ dan beberapa diantaranya juga memuat sekaligus sanksi perdata dan sanksi administratif. UU sektoral tersebut, antara lain yaitu: UU No. 5 Tahun 1960 tentang Pokok-Pokok Agraria (UU PA), UU No. 5 Tahun 1990 tentang Konservasi Sumber Daya Alam Hayati dan Ekosistemnya, UU No. 41 Tahun 1999 tentang Kehutanan, UU No. 22 Tahun 2001 tentang Minyak dan Gas Bumi, Perpu No. 1 Tahun 2004 tentang Perubahan Atas UU No. 41 Tahun 1999 tentang Kehutanan, UU No. 7 Tahun 2004 tentang Sumber Daya Air, ${ }^{2}$ UU No. 4 Tahun 2009 tentang Pertambangan Mineral dan Batubara, UU No. 18 Tahun 2013 tentang Pencegahan dan Pemberantasan Perusakan Hutan, dan UU No. 39 Tahun 2014 tentang Perkebunan. Namun, beberapa UU yang memuat sanksi administratif dan sekaligus sanksi pidana tidak memuat ketentuan yang menegaskan subsidiaritas sanksi pidana atas sanksi administratif. KUHP juga memuat pasal-pasal yang dapat digolongkan sebagai tindak pidana di bidang lingkungan hidup, yaitu tindak pidana yang menyebabkan kebakaran, peletusan, dan banjir, yang diatur dalam Pasal 187-Pasal 189.3 Di dalam Rancangan Kitab Undang-Undang Hukum Pidana (RUU KUHP), seluruh pengaturan tindak pidana lingkungan hidup dan sumber daya alam yang tersebar di beberapa undang-undang sektoral dimasukkan di dalam pasal-pasal RUU KUHP. Artinya pembentuk UU menghendaki penyelesaian kasus-kasus lingkungan hidup melalui hukum pidana. Dengan kata lain, hal ini sejalan dengan arah kebijakan UUPPLH.

Menurut Drupsteen, dari sudut pandang hukum lingkungan cukup jelas bahwa kemungkinan untuk mengatur masalah-masalah lingkungan dengan bantuan hukum pidana sangatlah terbatas. Pengaturan masalah lingkungan terutama harus dicapai melalui pelaksanaan kebijakan lingkungan oleh pihak

\footnotetext{
1 Berdasarkan UU No. 12 Tahun 2011 tentang Pembentukan Peraturan Perundang-Undangan, ketentuan pidana memuat rumusan yang menyatakan penjatuhan pidana atas pelanggaran terhadap ketentuan yang berisi norma larangan atau norma perintah.

2 Putusan Mahkamah Konstitusi (MK) No. 85/PUU-XI/2013 menghapus keberadaan seluruh pasal dalam UU No. 7 Tahun 2004 yang diajukan Pimpinan Pusat (PP) Muhammadiyah dkk, UU ini dianggap belum menjamin pembatasan pengelolaan air oleh pihak swasta, sehingga dinilai bertentangan UUD 1945. Dengan dibatalkannya keberadaan UU tersebut, MK menghidupkan kembali UU No. 11 Tahun 1974 tentang Pengairan untuk mencegah kekosongan hukum hingga adanya pembentukkan undang-undang baru.

${ }^{3}$ Wirjono Prodjodikoro, Tindak-Tindak Pidana Tertentu di Indonesia, Refika Aditama, Bandung, 2002, hlm. 133.
} 
penguasa. Kebijakan lingkungan tersebut, untuk sebagian, dirumuskan dalam norma-norma hukum atau peraturan perundang-undangan. Sebagian lainnya dirumuskan diluar norma hukum, misalnya melalui pendidikan lingkungan dan penciptaan kesadaran lingkungan. Jika kebijakan lingkungan tidak dirumuskan dalam bentuk norma hukum maka tidak dapat dilakukan penegakan hukum melalui pendayagunaan hukum pidana. Di pihak lain, bagi norma-norma hukum yang berkenaan dengan lingkungan, maka upaya penegakan hukum melalui sarana hukum pidana lebih merupakan pelengkap daripada instrumen pengatur. ${ }^{4}$

Berkaitan dengan itu, menurut Drupsteen, maka pengenaan sanksi dan penjagaan norma juga akan merupakan pertimbangan penting dalam upaya penegakan hukum lingkungan melalui sarana hukum pidana. Dalam hal ini, maka persoalan apakah upaya penegakan hukum lingkungan melalui sarana hukum pidana ini akan menimbulkan daya kerja preventif umum atau khusus tergantung pada berbagai macam faktor/variabel. Namun, terdapat banyak bentuk kriminalitas lingkungan yang hanya terjadi untuk sekali saja dan mengakibatkan perubahan yang permanen. Terhadap bentuk-bentuk kriminalitas lingkungan ini tidak ada pilihan yang cukup layak untuk menghadapinya kecuali melalui penggunaan sanksi pidana. ${ }^{5}$

\section{Rumusan Masalah}

Berdasarkan uraian di atas, maka permasalahan dalam penelitian ini adalah apakah asas ultimum remedium masih tepat/layak untuk diterapkan dalam bidang lingkungan hidup?

\section{Tujuan Penelitian}

Penelitian ini bertujuan untuk menganalisis kelayakan asas ultimum remedium di bidang lingkungan hidup. Secara akademis, penelitian ini diharapkan

\footnotetext{
4 G. Drupsteen dan C.J. Kleijs-Wijnnobel, Upaya Penegakan Hukum Lingkungan Melalui Hukum Perdata, Administratif, dan Hukum Pidana dalam Faure, J.C. Oudijk, D.D. Schaffmeister, Kekhawatiran Masa Kini. Pemikiran Mengenai Hukum Pidana Lingkungan Dalam Teori dan Praktek, Citra Aditya Bakti, Bandung, 1994, hlm. 6. ${ }^{5}$ Ibid.
} 
dapat memberikan sumbangan pemikiran bagi perkembangan ilmu pengetahuan di bidang hukum, khususnya terkait dengan asas ultimum remedium dalam bidang lingkungan hidup.

\section{Metode Penelitian}

Penelitian ini termasuk kategori penelitian hukum normatif atau penelitian hukum kepustakaan yaitu penelitian yang terutama menggunakan bahan pustaka atau data sekunder. ${ }^{6}$ Menurut Soetandyo Wignjosoebroto, penelitian hukum normatif adalah khusus untuk meneliti hukum sebagai norma positif, as it is written in the books atau yang lebih tepat disebut sebagai penelitian doktrinal. ${ }^{7}$ Penelitian doktrinal bertolak dari postulat-postulat normatif yang disebut dengan norma hukum positif dan doktrin-doktrin. ${ }^{8}$

Pendekatan yuridis yaitu pendekatan dalam memahami hukum dari kaidah normatif aturan hukum tersebut, merupakan pendekatan yang digunakan dalam penelitian ini karena yang menjadi objek penelitian adalah kebijakan pergeseran dari asas ultimum remedium ke asas primum remedium dalam tindak pidana lingkungan hidup.

Jenis data yang digunakan dalam penelitian ini, adalah data sekunder (dengan menggunakan bahan hukum primer dan bahan hukum sekunder) yang dikumpulkan melalui studi kepustakaan. Dalam penelitian ini, bahan hukum primer yang digunakan adalah UU tentang lingkungan hidup. Sedangkan bahan hukum sekunder berupa literatur yang terkait dengan objek yang diteliti. Bahan hukum yang diperoleh melalui studi pustaka kemudian dianalisis secara deskriptif kualitatif.

\footnotetext{
6 Soerjono Soekanto dan Sri Mamudji, Penelitian Hukum Normatif, Cetakan ketujuh, PT Raja Grafindo Persada, Jakarta, 2003, hlm. 13.

7 Soetandyo Wignjosoebroto, Hukum, Paradigma, Metode, dan Dinamika Masalahnya, Jakarta: Lembaga Studi dan Advokasi Masyarakat (ELSAM) dan perkumpulan untuk Pembaruan Hukum Berbasis Masyarakat dan Ekologi (HuMa), 2002, hal. 147. Menurut Soetandyo, di Indonesia, metode doktrinal ini terlanjur secara lazim disebut sebagai metode penelitian yang normatif, untuk melawankan dengan metode penelitian empiris (yang di dalam literatur internasional disebut penelitian nondoktrinal).

${ }^{8}$ Bambang Sunggono, Metodologi Penelitian Hukum (Suatu Pengantar), RajaGrafindo Persada, Jakarta, 1997, hlm. 92.
} 


\section{Hasil Penelitian dan Pembahasan}

\section{Permasalahan Lingkungan Hidup}

UU tentang PPLH membagi masalah lingkungan menjadi dua bentuk yaitu pencemaran lingkungan ${ }^{9}$ dan perusakan lingkungan. ${ }^{10}$ Sedangkan Stewart dan Krier, mengelompokkan masalah lingkungan menjadi: pencemaran lingkungan (pollution), pemanfaatan lahan secara salah (land misuse), dan pengurasan atau habisnya sumber daya alam (natural resource depeletion). Perbedaan pokok antara pencemaran lingkungan dengan terkurasnya sumber daya alam adalah bahwa pencemaran dapat terjadi karena masuknya atau hadirnya sesuatu zat, energi, atau komponen ke dalam lingkungan hidup atau ekosistem tertentu. Dengan demikian, zat, energi, atau komponen itu merupakan sesuatu yang asing atau yang pada mulanya tidak ada di dalam suatu kawasan lingkungan hidup kemudian hadir dalam kuantitas atau kualitas tertentu karena dimasukkan oleh kegiatan manusia. Sebaliknya, pengurasan sumber daya alam mengandung arti sumber daya alam yang terletak atau hidup di dalam konteks asalnya atau kawasan asalnya, kemudian oleh manusia diambil secara terus menerus dan tidak terkendali dengan cara dan jumlah tertentu sehingga menimbulkan perubahan dan penurunan kualitas lingkungan hidup. ${ }^{11}$

Dampak negatif dari penurunan kualitas lingkungan hidup baik karena terjadinya pencemaran atau terkurasnya sumber daya alam adalah timbulnya ancaman atau dampak negatif terhadap kesehatan, menurunnya nilai estetika, kerugian ekonomi (economic cost), dan terganggunya sistem alami (natural system). Dampak terhadap kesehatan manusia terutama bersumber dari pencemaran lingkungan. Dampak pencemaran lingkungan seringkali baru dapat dirasakan setelah beberapa tahun atau puluhan tahun sejak masuknya suatu zat ke dalam lingkungan hidup. Pencemaran lingkungan juga mengakibatkan rusaknya

\footnotetext{
${ }_{9}$ Berdasarkan UU tentang PPLH, pencemaran lingkungan hidup adalah masuk atau dimasukkannya makhluk hidup, zat, energi, dan/atau komponen lain ke dalam lingkungan hidup oleh kegiatan manusia sehingga melampaui baku mutu lingkungan hidup yang telah ditetapkan.

10 Berdasarkan UU tentang PPLH, perusakan lingkungan hidup adalah tindakan orang yang menimbulkan perubahan langsung atau tidak langsung terhadap sifat fisik, kimia, dan/atau hayati lingkungan hidup sehingga melampaui kriteria baku kerusakan lingkungan hidup.

11 Takdir Rahmadi, Hukum Lingkungan di Indonesia, RajaGrafindo Persada, Jakarta, 2014, hlm. 1-3.
} 
estetika dari lingkungan hidup atau lingkungan tempat tinggal manusia, seperti: gangguan adanya bau, kebisingan, asap atau kabut. Selain itu, kerugian ekonomi akan diderita oleh korban pencemaran atau perusakan lingkungan. Pada akhirnya masalah-masalah lingkungan akan dapat mengubah sistem alami. Penggundulan hutan, lahan kritis, menipisnya lapisan ozon, pemanasan global tumpahan minyak di laut, ikan mati di anak sungai karena zat-zat kimia, dan punahnya spesies tertentu merupakan masalah-masalah lingkungan hidup yang dapat mengubah sistem alami. ${ }^{12}$

Demikian pula perusakan lingkungan hidup akibat penebangan hutan Indonesia yang tidak terkendali selama puluhan tahun dan menyebabkan terjadinya penyusutan hutan tropis secara besar-besaran sangat berdampak terhadap keadaan ekosistem di Indonesia. Penebangan memberi dampak yang sangat merugikan masyarakat sekitar, bahkan masyarakat dunia. Kerugian yang diakibatkan oleh kerusakan hutan tidak hanya kerusakan secara nilai ekonomi, akan tetapi juga mengakibatkan hilangnya nyawa yang tidak ternilai harganya. Dampak lainnya adalah hilangnya paru-paru Indonesia dan dunia. Pemanasan global, akan diikuti perubahan iklim seperti naiknya curah hujan di beberapa belahan bumi yang menimbulkan bencana banjir dan tanah longsor, tetapi sebaliknya di belahan bumi lainnya mengalami kekeringan berkepanjangan. ${ }^{13}$

Pencemaran lingkungan hidup dapat melintasi batas-batas negara dalam bentuk pencemaran air sungai, emisi udara, kebakaran hutan, pencemaran minyak di laut, dan sebagainya. ${ }^{14}$ Yang lebih memprihatinkan adalah, bahwa kejahatan lingkungan dalam bentuk illegal disposal of dangerous waste di pelbagai negara sudah menjurus ke arah kejahatan transnasional yang terorganisasi dan secara serius hal ini dibahas dalam The World Ministerial Conference on Organized Transnational Crimes di Napoli pada 21-23 Nopember 1994. Secara konseptual hal ini sejalan dengan pemahaman bahwa tindak pidana yang melanggar ketentuan tentang perlindungan lingkungan merupakan salah satu kejahatan kriminal. Hal

\footnotetext{
${ }^{12}$ Ibid., hlm. 1.

13 Bambang Tri Bawono, dan Anis Mashdurohatun, "Penegakan Hukum Pidana di Bidang Illegal Logging bagi Kelestarian Lingkungan Hidup dan Upaya Penanggulangannya", Jurnal Hukum Vol Xxvi, No. 2, Agustus 2011, hlm. 601.

14 Andi Hamzah, Penegakan Hukum Lingkungan, Sinar Grafika, Jakarta, 2008, hlm. 58.
} 
ini berkaitan dengan kenyataan bahwa kejahatan lingkungan seringkali mempunyai dampak internasional atau transnasional. ${ }^{15}$

Oleh karena itu, permasalahan lingkungan hidup, apabila dikaitkan dengan masalah hak-hak asasi manusia, tidak saja merupakan persoalan negara per negara, tetapi juga menjadi persoalan regional bahkan internasional (antar bangsa). Hal ini nampak dari program kerja The Commission on Crime Prevention and Criminal Justice 1992-1996 yang menyoroti secara khusus keterkaitan antara masalah lingkungan hidup dengan sistem peradilan pidana. Atas dasar itulah, Kongres ke 9 PBB tentang Pencegahan Kejahatan dan Pembinaan Para Pelaku pada tanggal 29 April-8 Mei 1995 di Kairo, menjadikan masalah lingkungan hidup sebagai salah satu agenda utama. Di dalam draft resolusi yang diajukan, yang kemudian menjadi resolusi, sepanjang menyangkut "perlindungan lingkungan" terdapat beberapa hal sebagai berikut. ${ }^{16}$

"(1) The right to enjoy an adequate environment and the duty to preserve the environment should be established in all legislation at the national level;(2) A chapter concerning environmental offenses should be included in penal codes;(3)The necessary measures should be introduced to ensure that damage to the environment is repaired, either by the transgressors themselves or by the State;(4) Cooperation agreements should be established between states, including provisions for the exchange of experiences on prevention programmes and legislative effectiveness; (5) Subject of environmental protection should be included at all educational level, and specifically in curricula for the study of criminal law and human resources should also be developed to deal with these new problem, by means of degree courses, post graduate courses, seminars and any other form of training;(6) Not only should environment offences be established as a class of offence in penal codes, but also, in the administrative area, offending enterprises should be subject to financial penalties;(7)Regarding penal sanctions themselves, the principle of subjective culpability should be maintained."

Apa yang dirumuskan dalam resolusi tersebut tidaklah berlebihan, karena hak untuk memperoleh lingkungan hidup yang sehat merupakan salah satu hak asasi yang diatur dalam Universal Declaration of Human Right, 1948 (Art. 25) jo Art.11International Convenant on Economic, Social and Cultural Rights (1966). Demikian pula di dalam Paragraf 1 UN Conference on the Environment di Stockholm tahun 1972, The Optional Protocol dari International Convenant on Economic, Social and Cultural Rights, Art. 12, dan Laporan Akhir (1985) dari the World Expert Group

${ }_{15}$ Muladi, Demokratisasi, Hak Asasi Manusia, dan Reformasi Hukum di Indonesia, The Habibie Center, Jakarta, 2002, hlm. 94.

16Ibid., hlm. 91. 
on Environmental Law kepada the Brundtland Commission (Art. 1 dan 2), hak untuk memperoleh lingkungan hidup yang sehat selalu ditegaskan. Penegasan secara global terjadi pada the UN Conference on Environment and Development di Rio de Janeiro, pada tahun 1992.17Hak untuk mendapatkan lingkungan hidup yang baik dan sehat juga ditegaskan dalam Pasal 28H Undang-Undang Dasar Negara Republik Indonesia Tahun 1945.

Penjelasan Umum beberapa UU yang terkait dengan lingkungan hidup menggambarkan bagaimana masalah-masalah lingkungan hidup sudah semakin mengkhawatirkan dan telah mengancam kelangsungan perikehidupan manusia dan makhluk hidup lainnya, sehingga beberapa UU ini menyebutkan pentingnya memperhatikan asas-asas lingkungan hidup.Penjelasan Umum UU No. 18 Tahun 2013 misalnya, menyebutkan bahwa perusakan hutan telah mencapai tingkat yang sangat mengkhawatirkan bagi kelangsungan hidup bangsa dan negara. ${ }^{18}$ Beberapa UU yang terkait dengan lingkungan hidup juga memuat sanksi administratif, sanksi perdata, dan sekaligus sanksi pidana, sebagian memuat ketentuan yang menegaskan subsidiaritas sanksi pidana atas sanksi administratif atau sanksi perdata.

Herbert L. Packer dalam bukunya The Limit of Criminal Sanction, berkaitan dengan pembenaran pidana, menyimpulkan antara lain bahwa sanksi pidana merupakan alat atau sarana terbaik yang tersedia, yang kita miliki untuk menghadapi bahaya-bahaya besar dan segera serta untuk menghadapi ancamanancaman dari bahaya. ${ }^{19}$ Sebagaimana pula kaum konsekuensialis yang berpendapat bahwa adanya pidana dibenarkan apabila pidana itu membawa kebaikan, pidana mencegah kejadian yang lebih buruk, dan tidak ada alternatif lain yang dapat memberikan hasil yang setara baiknya (atau buruknya). ${ }^{20}$

${ }^{17}$ Ibid., hlm. 92.

18Misalnya dalam UU No. 5 Tahun 1960 tentang Pokok-Pokok Agraria (UU PA), UU No. 11 Tahun 1974 tentang Pengairan, UU No. 5 Tahun 1990 tentang Konservasi Sumber Daya Alam Hayati dan Ekosistemnya, UU No. 41 Tahun 1999 tentang Kehutanan, UU No. 22 Tahun 2001 tentang Minyak dan Gas Bumi, Perpu No. 1 Tahun 2004 tentang Perubahan Atas UU No. 41 Tahun 1999 tentang Kehutanan, UU No. 4 Tahun 2009 tentang Pertambangan Mineral Dan Batubara, UU No. 18 Tahun 2013 tentang Pencegahan dan Pemberantasan Perusakan Hutan, dan UU No. 39 Tahun 2014 tentang Perkebunan.

${ }^{19}$ Herbert L. Packer, The Limit of The Criminal Sanction, Stanford University Press, California, 1968, hlm. 344346.

${ }^{20}$ Duff, R.A. and David Garland, A Reader on Punishment, University Press, Oxford, 1994, hlm. 6 - 8. 
Melihat dari tingkat kerusakan yang ditimbulkan, masih tepat/layakkah asas ultimum remedium yang menempatkan hukum pidana sebagai ultimum remidium terhadap para pelaku perusakan lingkungan diterapkan? Dapatkah sanksi administratif yang diberikan membuat para perusak lingkungan menjadi jera? Karena asas ultimum remedium ini menempatkan sanksi pidana sebagai ultimum remidium. Ini berarti sanksi pidana merupakan jalan terakhir untuk memberikan punishment terhadap para perusak lingkungan. Maksud dari asas ultimum remedium ini adalah untuk mengutamakan perbaikan lingkungan yang rusak akibat kegiatan orang/badan usaha tersebut. Pada kenyataannya, pelaku perusakan yang merupakan korporasi adalah orang-orang yang mempunyai modal/capital yang sangat besar. Besarnya denda yang harus mereka bayar untuk memenuhi sanksi administratif bukanlah masalah besar bagi mereka.

\section{Prinsip Ultimum Remedium terhadap Masalah Lingkungan Hidup}

Baik UU No. 4 Tahun 1982 maupun UU No. 23 Tahun 1997 pada dasarnya bertitik tolak dari hukum administratif. Hal ini dapat dilihat dengan memperhatikan judul kedua undang-undang tersebut yaitu "Pengelolaan Lingkungan Hidup". Pengelolaan dikaitkan dengan wewenang dan wewenang itu sendiri merupakan fokus utama hukum administratif. Namun demikian, tidak serta merta dapat disimpulkan bahwa hukum lingkungan dengan sendirinya hukum administratif. ${ }^{21}$ Sebagaimana penjelasan UU No. 23 Tahun 1997 yang menyebutkan bahwa “...pendayagunaan berbagai ketentuan hukum, baik hukum administratif, hukum perdata maupun hukum pidana, dan usaha untuk mengefektifkan penyelesaian sengketa lingkungan hidup secara alternatif, yaitu penyelesaian sengketa lingkungan hidup di luar, kemungkinan dilakukannya gugatan perwakilan. Sedangkan berlakunya ketentuan hukum pidana, berdasarkan UU ini, tetap memperhatikan asas subsidiaritas, yaitu bahwa hukum pidana hendaknya didayagunakan apabila sanksi bidang hukum lain, seperti sanksi administratif dan sanksi perdata, dan alternatif penyelesaian sengketa

\footnotetext{
${ }^{21}$ Prosiding "Seminar Pemikiran Perubahan UU No. 23 Tahun 1997 tentang Pengelolaan Lingkungan Hidup”, Kementerian Lingkungan Hidup, Jakarta, Hotel Indonesia, 15 Desember 2003, hlm. 40.
} 
lingkungan hidup tidak efektif dan/atau tingkat kesalahan pelaku relatif berat dan/atau akibat perbuatannya relatif besar dan/atau perbuatannya menimbulkan keresahan masyarakat.

Sebelum disahkan dan menjadi UU No. 32 Tahun 2009, RUU perubahan atau penggantian atas UU No. 23 Tahun 1997 juga berjudul "Pengelolaan Lingkungan Hidup". Namun dalam perkembangan pembahasannya, diputuskan untuk menambah kata Perlindungan sehingga menjadi RUU Perlindungan dan Pengelolaan Lingkungan Hidup. Penambahan kata "perlindungan" sebelum kata "pengelolaan" untuk memberikan pesan bahwa RUU ini ditujukan untuk melindungi wilayah negara kesatuan Republik Indonesia dari pencemaran dan/atau perusakan lingkungan hidup. 22

Perubahan judul dari hanya pengelolaan menjadi perlindungan dan pengelolaan untuk semakin menguatkan pesan, lingkungan boleh dimanfaatkan namun harus dijaga kelestariannya. ${ }^{23} \mathrm{Hal}$ ini sejalan dengan perkembangan hukum lingkungan internasional modern yang tidak hanya memberi hak kepada manusia untuk memakai lingkungan tetapi juga membebani manusia dengan suatu kewajiban untuk menjaga, melindungi, dan melestarikannya. ${ }^{24}$

Perlindungan dan pengelolaan lingkungan hidup berdasarkan Pasal 1 angka 2 UU No. 32 Tahun 2009 adalah upaya sistematis dan terpadu yang dilakukan untuk melestarikan fungsi lingkungan hidup dan mencegah terjadinya pencemaran dan/atau kerusakan lingkungan hidup yang meliputi perencanaan, pemanfaatan, pengendalian, pemeliharaan, pengawasan, dan penegakan hukum. Sebagaimana Penjelasan UU ini, bahwa upaya preventif dalam rangka pengendalian dampak lingkungan hidup perlu dilaksanakan dengan mendayagunakan secara maksimal instrumen pengawasan dan perizinan.

22 Laporan Pimpinan Komisi VII DPR RI dalam Pengambilan Keputusan dalam Rapat Paripurna ke-6 Dewan Perwakilan Rakyat Republik Indonesia Masa Persidangan I Tahun Sidang 2009-2010 pada 8 September 2009, dalam Risalah Proses Pembahasan RUU tentang Pengelolaan Lingkungan Hidup.

23 Pendapat Akhir Fraksi PKS dalam Pengambilan Keputusan dalam Rapat Paripurna ke-6 Dewan Perwakilan Rakyat Republik Indonesia Masa Persidangan I Tahun Sidang 2009-2010 pada tanggal 8 September 2009, dalam Risalah Proses Pembahasan RUU tentang Pengelolaan Lingkungan Hidup.

${ }^{24}$ Sejak Deklarasi Stockholm 1972, hukum lingkungan berubah sifatnya dari use-oriented menjadi environmentoriented. Hukum lingkungan yang bersifat use-oriented maksudnya produk hukum yang hanya memberikan hak kepada masyarakat untuk mengekspolitasi lingkungan dan sumber daya alam tanpa membebani kewajiban untuk menjaga, melindungi, dan melestarikannya. Sukanda Husin, Penegakan Hukum Lingkungan Indonesia, Sinar Grafika, Jakarta, 2009, hlm. 20. 
Namun dalam hal pencemaran dan kerusakan lingkungan hidup sudah terjadi, perlu dilakukan upaya represif berupa penegakan hukum yang efektif, konsekuen, dan konsisten terhadap pencemaran dan kerusakan lingkungan hidup yang sudah terjadi. Penjelasan UU No. 32 Tahun 2009 juga menyebutkan bahwa terkait dengan hal tersebut, perlu dikembangkan satu sistem hukum perlindungan dan pengelolaan lingkungan hidup yang jelas, tegas, dan menyeluruh guna menjamin kepastian hukum sebagai landasan bagi perlindungan dan pengelolaan sumber daya alam serta kegiatan pembangunan lain.

Dengan demikian, penegakan hukum terhadap perlindungan dan pengelolaan lingkungan hidup berdasarkan UU No. 32 Tahun 2009 melalui 3 (tiga) langkah penegakan hukum secara sistematis, yaitu mulai dengan penegakan hukum administratif, penyelesaian sengketa di luar pengadilan dan penyidikan atas tindak pidana lingkungan hidup. Menurut Rangkuti, dalam bidang lingkungan hidup, sanksi administratif mempunyai fungsi instrumental yaitu pengendalian perbuatan terlarang dan terutama ditujukan kepada perlindungan kepentingan yang dijaga oleh ketentuan yang dilanggar tersebut. ${ }^{25}$ Sedangkan ketentuan hukum perdata meliputi penyelesaian sengketa lingkungan hidup di luar pengadilan dan di dalam pengadilan. Penyelesaian sengketa lingkungan hidup di dalam pengadilan meliputi gugatan perwakilan kelompok, hak gugat organisasi lingkungan, ataupun hak gugat pemerintah. Melalui cara tersebut diharapkan selain akan menimbulkan efek jera juga akan meningkatkan kesadaran seluruh pemangku kepentingan tentang betapa pentingnya perlindungan dan pengelolaan lingkungan hidup demi kehidupan generasi masa kini dan masa depan.

Penegakan hukum pidana dalam UU ini tetap memperhatikan asas ultimum remedium yang mewajibkan penerapan penegakan hukum pidana sebagai upaya terakhir setelah penerapan penegakan hukum administratif dianggap tidak berhasil. Penerapan asas ultimum remedium ini hanya berlaku bagi tindak pidana

25 Sri Sundari Rangkuti, Hukum Lingkungan dan Kebijaksanaan Lingkungan Nasional, Airlangga University Pers, Surabaya, 2000, hlm. 211. 
formil tertentu, yaitu pemidanaan terhadap pelanggaran baku mutu air limbah, ${ }^{26}$ emisi, ${ }^{27}$ dan gangguan. ${ }^{28}$ Dengan kata lain, pelanggaran terhadap selain baku mutu air limbah, emisi, dan gangguan berlaku asas premium remedium (mendahulukan pelaksanaan penegakan hukum pidana).

Istilah ultimum remedium pertama kali diucapkan oleh Menteri Kehakiman Belanda, Mr. Modderman. ${ }^{29}$ Menurut Modderman, asas ultimum remedium adalah: bahwa yang dapat dihukum, pertama, adalah pelanggaran-pelanggaran hukum. Ini merupakan conditio sine qua non. Kedua, adalah bahwa yang dapat dihukum itu adalah pelanggaran-pelanggaran hukum, yang menurut pengalaman tidaklah dapat ditiadakan dengan cara-cara yang lain. Hukuman itu hendaklah merupakan suatu upaya yang terakhir. ${ }^{30}$ Pendapat ini selaras dengan apa yang dikemukakan oleh Remmelink, bahwa pidana sebagai hukum yang bersanksi tajam pada asasnya hanya akan dijatuhkan, apabila mekanisme penegakan hukum lainnya yang lebih ringan telah tidak berdaya guna atau sudah sebelumnya dipandang tidak cocok. ${ }^{31}$ Dengan demikian, jika pihak penguasa berpendapat bahwa tujuan-tujuannya dapat dicapai dengan mendayagunakan peraturan-peraturan di bidang keperdataan, administratif, hukum disipliner atau pengaturan kemasyarakatan faktual lainnya, maka hukum pidana baik untuk sebagian maupun keseluruhan tidak akan difungsikan. ${ }^{32}$

Sedangkan menurut De Bunt, ultimum remedium mempunyai tiga pengertian, yaitu: Pertama, hukum pidana hanya diterapkan terhadap perbuatanperbuatan yang sangat tidak benar secara etis. Pada tahun 1989, Menteri kehakiman Belanda pernah menyatakan bahwa hukum pidana pada umumnya

26 Penjelasan Pasal 20 ayat (2) huruf b: yang dimaksud dengan "baku mutu air limbah" adalah ukuran batas atau kadar polutan yang ditenggang untuk dimasukkan ke media air .

${ }_{27}$ Penjelasan Pasal 20 ayat (2) huruf e: yang dimaksud dengan "baku mutu emisi" adalah ukuran batas atau kadar polutan yang ditenggang untuk dimasukkan ke media udara.

28 Penjelasan Pasal 20 ayat (2) huruf f: yang dimaksud dengan "baku mutu gangguan" adalah ukuran batas unsur pencemar yang ditenggang keberadaannya yang meliputi unsur getaran, kebisingan, dan kebauan.

29 Istilah ultimum remedium pertama kali dipergunakan oleh Modderman di depan parlemen negeri Belanda untuk menjawab pernyataan salah seorang anggota parlemen Belanda, Mackay, yang mengatakan bahwa ia telah gagal menemukan suatu dasar hukum mengenai perlunya suatu penjatuhan hukuman bagi seseorang yang telah melakukan suatu pelanggaran. Dikutip dari P.A.F. Lamintang, Dasar-Dasar Hukum Pidana Indonesia, Citra Aditya Bakti, Bandung, 1997, hlm. 17-19

${ }^{30}$ Ibid.

${ }^{31}$ Jan Remmelink, Hukum Pidana. Komentar Atas Pasal-Pasal Terpenting dari Kitab Undang-Undang Hukum Pidana Belanda dan Padanannya dalam Kitab Undang-Undang Hukum Pidana, Gramedia Pustaka Utama, Jakarta, 2003, hlm. 15.

32 Ibid., hlm. 28. 
harus dilihat sebagai ultimum remedium. Artinya, bahwa perbuatan beratlah yang harus ditanggulangi oleh hukum pidana. Dalam hal ini, pengertian ultimum remedium diartikan secara klasik; hukum pidana secara khusus merupakan instrumen penegakan hukum yang khusus. Harus dicegah bahwa obat jangan lebih berat daripada kejahatan. Hukum pidana merupakan alat yang sangat berat karena ciri khas pidana adalah nestapa yang dengan sengaja dikenakan. Oleh karena itu, hukum pidana harus dipandang sebagai ultimum remedium. ${ }^{33}$ Kedua, ultimum remedium menurut De Bunt adalah dalam arti harfiah, yaitu alat (obat) yang terakhir. Hal ini dikemukakan oleh Menteri Kehakiman Belanda De Ruiter yang menyatakan bahwa hukum pidana sebagai alat yang terakhir. Hukum pidana menjadi obat yang terakhir karena membawa dampak sampingan yang merugikan. Hukum pidana menyinggung sangat dalam terhadap kehidupan pribadi terpidana (perampasan kemerdekaan, proses acara dengan alat paksa, dan noda). ${ }^{34}$ Hukum pidana sebagai obat terakhir juga dikemukakan oleh Sudarto. Menurut Sudarto, hukum pidana hendaknya baru diterapkan jika sarana (upaya) lain sudah tidak memadai, maka dikatakan pula bahwa hukum pidana mempunyai fungsi yang subsidiair (asas subsidiaritas). ${ }^{35}$ Ketiga, pengertian ultimum remedium yaitu pejabat administratiflah yang pertama-tama harus bertanggung jawab. Jika pejabat administratif dipandang sebagai yang pertamatama bertanggung jawab, dan oleh karena itu berarti bahwa kekuasaan yustisial ditempatkan sebagai ultimum remedium. Pejabat administratif harus bereaksi terlebih dahulu. Pejabat yang memberi ijin harus terlebih dahulu memberi sanksi jika ijin dilanggar. ${ }^{36}$

Pidana sebagai ultimum remedium, terkait dengan apa yang dikemukakan oleh Sudarto, bahwa faktor penyebab terjadinya kejahatan sangat kompleks dan berada di luar jangkauan hukum pidana. Wajarlah hukum pidana mempunyai keterbatasan kemampuan untuk menanggulanginya. Penggunaan hukum pidana merupakan penanggulangan sesuatu gejala dan bukan suatu penyelesaian

\footnotetext{
33 Andi Hamzah, Penegakan Hukum Lingkungan, Sinar Grafika, Jakarta, 2008, hlm. 69.

${ }^{34}$ Ibid., hlm. 70.

35 Sudarto, Hukum dan Hukum Pidana, Alumni, Bandung, 2007, hlm. 22.

36 Andi Hamzah, Penegakan Hukum..., Op. Cit., hlm. 71.
} 
dengan menghilangkan sebab-sebabnya. ${ }^{37}$ Keterbatasan kemampuan hukum pidana disebabkan oleh sifat/hakikat dan fungsi dari hukum pidana itu sendiri. Sanksi hukum pidana bukanlah obat (remedium) untuk mengatasi sebab-sebab (sumber) penyakit, tetapi sekadar untuk mengatasi gejala/akibat dari penyakit. Dengan kata lain, sanksi (hukum) pidana bukanlah "pengobatan kausatif", tapi sekedar "pengobatan simptomatik. 38

Selanjutnya apabila hukum pidana digunakan maka reaksi hukum pidana harus setimpal secara layak atau proporsional dengan apa yang sesungguhnya diperbuat oleh pelaku tindak pidana. Terhadap tindak pidana harus dimunculkan reaksi yang adil.39 Dalam menggunakan hukum pidana, Nigel Walker mengemukakan beberapa asas pembatas (the limiting principles) penggunaan hukum pidana, yaitu: 1. prohibitions should not be included in the criminal law for the sole purpose of ensuring that breaches of them are visited with retributive punishment; 2. the criminal law should not be used to penalize behaviour which does no harm; 3 . the criminal law should not be used to achieve a purpose which can be achieved as effectively at less cost in suffering; 4. the criminal law should not be used if the harm done by the penalty is greater than the harm done by the offence; 5. the criminal law should not be used for the purpose of compelling people to act in their own best interests; 6 . the criminal law should not include prohibitions which do not have strong public support; 7. a prohibition should not be included in the criminal law if it is unenforceable. 40

Herbert L. Packer mengajukan pula beberapa kriteria penggunaan hukum pidana sebagai sarana penanggulangan kejahatan, khususnya mengenai perbuatan apa yang sebaiknya diatur oleh hukum pidana, yaitu: 1. the conduct is promin; 2. ent in most people's view of socially threatening behavior, and is not condoned by any significant segment of society; 3 . subjecting it to the criminal sanction is not inconsistent with the goals of punishment; 4. suppressing it will not inhibit socially

\footnotetext{
${ }^{37}$ Sudarto, Hukum Pidana dan Perkembangan Masyarakat, dalam Barda Nawawi Arief, Beberapa Aspek Kebijakan Penegakan dan Pengembangan Hukum Pidana, Citra Aditya Bakti, Bandung, 1998, hlm. 44.

38 Keterbatasan kemampuan hukum pidana antara lain dapat dilihat dari sifat/fungsi pemidanaan selama ini, yaitu pemidanaan individual/personal, dan bukan pemidanaan yang bersifat struktural/fungsional. Pemidanaan yang bersifat individual/personal kurang menyentuh sisi-sisi lain yang berhubungan erat secara struktural/fungsional dengan perbuatan (dan akibat perbuatan) si pelaku. Sisi lain yang bersifat struktural fungsional ini misalnya pihak korban/penderita lainnya dan struktur/kondisi lingkungan yang menyebabkan si pembuat melakukan kejahatan/tindak pidana.Barda Nawawi Arief, Beberapa Aspek Kebijakan Penegakan dan Pengembangan Hukum Pidana, Citra Aditya Bakti, Bandung, 1998, hlm. 44.

${ }^{39}$ Jan Remmelink, Hukum Pidana..., hlm. 15.

${ }^{40}$ Nigel Walker, Sentencing in a rational Society, Allen Lane The Penguin Press, London, 1969, hlm. 26-36.
} 
desirable conduct; 5. it may be dealt with through even-handed and nondiscriminatory enforcement. 6. controlling it through the criminal process will not expose that process to severe qualitative or quantitative strains; 7 . there are no reasonable alternatives to the criminal sanction for dealing with it. ${ }^{41}$

Mengacu pada pengertian mengenai ultimum remedium dan asas pembatas atau kriteria penggunaan hukum pidana maka bagaimana pengaturan hukum pidana terhadap pencemaran dan perusakan lingkungan hidup? Perbuatan pencemaran dan perusakan lingkungan hidup merupakan perbuatan yang secara langsung atau tidak langsung dapat membahayakan kehidupan dan jiwa manusia. Hukum pidana pada dasarnya bertujuan untuk melindungi jiwa dan kehormatan manusia dan harta benda. Ketika pencemaran dan perusakan lingkungan hidup telah menimbulkan dampak negatif terhadap kehidupan manusia, maka perbuatan tersebut harus dipandang sebagai perbuatan yang bertentangan dengan moral dan layak untuk dikenakan sanksi pidana.

Tindak pidana lingkungan pada masa lalu dapat dianggap sebagai ultimum remedium tetapi tuntutan internasional menghendaki agar fungsi hukum pidana dalam tindak pidana lingkungan (echo-crime) menjadi primum remedium. ${ }^{42}$ The Council of Europe Resolution 77 (28) menegaskan perlunya kontribusi hukum pidana dalam rangka perlindungan terhadap lingkungan hidup. UN General Assembly Resolution No. 45/121 tahun 1990 juga menerima resolusi tentang proteksi lingkungan hidup dengan hukum pidana yang diajukan oleh the Eighth UN Congress on the Prevention of Crime and the Treatment of Offenders. Demikian pula Rekomendasi dari the AIDP Preparatory Colloquium on the Apllication of Criminal Law to Crime Against the Environment di Ottawa, Kanada (1992) menegaskan perlunya dipertimbangkan penggunaan hukum pidana untuk melindungi kelestarian lingkungan hidup. Selanjutnya pada Maret 1994, di Portland, Oregon, USA, diselenggarakan International Meeting of Experts on Environmental Crime.Dalam pertemuan itu dibahas tentang penggunaan sanksi

${ }^{41}$ H.L. Packer, The Limit of Criminal Sanction, Stanford University Press, California, 1968, hlm. 297.

${ }^{42}$ Muladi, Beberapa Catatan Dalam RUU KUHP, dalam Lembaga Studi dan Advokasi Masyarakat (ELSAM), Beberapa Tulisan Terkait Kebijakan Kriminal Dalam RUU KUHP, ELSAM, Jakarta, 2006, hlm. 76. 
pidana dalam kerangka perlindungan lingkungan dalam lingkup internasional, regional, dan domestik yang kemudian menghasilkan The Portland Draft. ${ }^{43}$

Menurut Muladi, peranan hukum pidana dalam melindungi lingkungan hidup semakin penting. Bahkan dalam kasus-kasus pencemaran dan perusakan lingkungan hidup yang berat, sifatnya sebagai "primum remedium" semakin nampak. ${ }^{4}$ Demikian pula Alvi Syahri yang menyatakan bahwa ultimum remedium dapat dikesampingkan dalam hal tindak pidana yang dilakukan merupakan suatu pelanggaran terhadap hak subyektif maupun kepentingan masyarakat luas. ${ }^{45}$ Bahkan di Belanda, pendapat yang mengatakan bahwa penerapan hukum pidana merupakan ultimum remedium telah ditinggalkan, karena hal itu menimbulkan pertengkaran antara pejabat administrasi dan penuntut umum tentang kapan saatnya penggunaan ultimum remedium (hukum pidana) itu. ${ }^{46}$

Pada kenyataannya, sanksi pidana dan sanksi administratif tidak dapat dibedakan secara tegas sehingga membawa konsekuensi tertentu sebagai berikut. Pertama, menurut G. Drupsteendan C.J. Kleijs Wijnnobel, tidak dapat diberlakukannya asas prioritas, dalam arti mendahulukan upaya penegakan hukum melalui hukum administratif atas upaya penegakan hukum melalui sarana hukum pidana.Van der Bunt telah menunjukkan bahwa sifat dasar hukum pidana sebagai ultimum remedium memiliki berbagai pengertian. ${ }^{47}$ Namun terlepas dari efektivitas sanksi dan unsur pengenaan penderitaan, sanksi administratif masih dapat dibedakan dengan cukup jelas dari sanksi pidana. Selain itu pertimbangan-pertimbangan praktis juga perlu dipertimbangkan, misalnya kapasitas/kemampuan penegakan hukum lingkungan.Terkait dengan hal ini, diberikannya kemampuan/kapasitas untuk melakukan penyidikan dan penuntutan yang terbatas berarti bahwa harus dilakukannya penentuan prioritas. Menurut Drupsteendan Wijnnobel, dalam hal ini, ultimum remedium, tidak harus ditempatkan dalam urutan terakhir. Faktor yang menentukan penetapan prioritas

${ }^{43}$ Muladi, Demokratisasi, Hak Asasi Manusia, dan Reformasi Hukum di Indonesia, The Habibie Center, Jakarta, 2002, hlm. 93.

${ }^{44}$ Ibid., hlm. 106.

${ }^{45}$ Alvi Syahrin, Beberapa Isu Hukum Lingkungan Kepidanaan, Sofmedia, Jakarta, 2009, hlm.10.

${ }^{46}$ International Environmental Law Workshop, dalam Andi Hamzah, Penegakan Hukum..., Op. Cit., hlm. 72.

${ }^{47}$ G. Drupsteen dan C.J. Kleijs Wijnnobel, Upaya Penegakan Hukum Lingkungan Melalui Hukum Perdata, Administratif, dan Hukum Pidana, dalam Faure, J.C. Oudijk, D.D. Schaffmeister, Kekhawatiran Masa Kini. Pemikiran Mengenai Hukum Pidana Lingkungan Dalam Teori dan Praktek, Citra Aditya Bakti, Bandung, 1994, hlm. 19. 
adalah, antara lain, tingkat keseriusan tindak pidana, sifat/karakter pidana tersebut dan kemungkinan penegakkan hukum oleh pihak pemerintah atau lembaga kejaksaan. ${ }^{48}$

Kedua, konsekuensi dari perbedaan relatif antara sanksi administratif dan sanksi pidana adalah bahwa dalam penjatuhan kedua sanksi tersebut secara bersamaan, asas ne bis in idem, kemudian, tidak lagi begitu mudah untuk diabaikan atau disimpangi dengan cara menunjuk pada perbedaan ruang lingkup kedua macam sanksi tersebut. Dalam hal ini harus dilihat kasus per kasus. Akan tetapi kita tidak dapat menyatakan bahwa kemungkinan pelaksanaan upaya paksa disamping penjatuhan putusan peradilan pidana akan menjadi tertutup. Cara yang pertama bertujuan menghilangkan akibat kerusakan lingkungan, misalnya melalui perintah untuk menyingkirkan limbah yang dibuang secara illegal. Cara yang kedua, menambahkan penderitaan tambahan melalui penjatuhan pidana denda atau kurungan. Menurut pandangan yang berlaku, larangan ne bis in idem, tidak berkenaan dengan penjatuhan sanksi pidana dan sanksi administratif secara bersamaan atas suatu tindak pidana yang sama. Asas tersebut berlaku bagi penuntutan pidana untuk kedua kali atas satu kasus yang sama. Sebaliknya, penyelesaian suatu kasus melalui penjatuhan sanksi administratif tidak akan menghalangi penuntutan pidana atas kasus yang sama. ${ }^{49}$ Demikian pula Muladi yang menyatakan bahwa pendayagunaan peradilan administratif dan hukum pidana tidak akan merupakan ne bis in idem, tetapi sebaiknya hal tersebut dilakukan setelah mempertimbangkan tingkat kesalahan si pelaku dan berat ringannya kerusakan terhadap lingkungan akibat tindak pidana yang dilakukan. Di sinilah letak pentingnya peranan penyidik pegawai negeri sipil (PPNS).50 Namun menurut Drupsteen dan Wijnnobel, pandangan ini kurang tepat dan masih harus dilakukan pembedaan yang didasarkan atas sifat sanksi administratif tersebut. Jika sanksi ini tidak mengandung sifat memperbaiki (reparatoir), namun retributif, yakni dalam arti bahwa sanksi tersebut bersifat menghukum dan memberikan penderitaan, maka

\footnotetext{
48 Ibid., hlm. 19.

49 Ibid., hlm. 20.

${ }^{50}$ Muladi, Demokratisasi..., Op. Cit., hlm. 97.
} 
seharusnya tertutup kemungkinan untuk menjatuhkan pidana ini bersamaan dengan sanksi pidana. ${ }^{51}$

Ketiga, konsekuensi dari perbedaan relatif antara sanksi administratif dan sanksi pidana adalah bahwa jangka waktu penyelesaian perkara dan saran agar hakim dengan memperhatikan asas-asas umum pemerintahan yang baik dapat menilai kesesuaian/keseimbangan antara perbuatan yang dilakukan (tindak pidananya) dengan sanksi yang akan dijatuhkan terhadap si pelaku. ${ }^{52}$

Permasalahan lingkungan hidup berupa pencemaran dan kerusakan lingkungan sudah semakin kompleks dan cenderung sulit untuk tertangani dengan baik, indikasi ini terlihat dengan semakin menurunnya kualitas lingkungan hidup di beberapa wilayah Indonesia, yang tentunya dapat mengancam: kelangsungan dan keberlanjutan peri kehidupan manusia dan makhluk hidup lainnya. Permasalahan lingkungan menjadi semakin kompleks karena tidak hanya bersifat praktis atau konseptual ekonomi saja tetapi juga merupakan masalah etika baik sosial maupun bisnis. Yang dilindungi oleh hukum pidana tidak hanya alam, flora dan fauna (the ecological approach) tetapi juga masa depan kemanusiaan yang kemungkinan menderita akibat degradasi lingkungan hidup. Dengan demikian muncul istilah "the environmental laws carry penal sanctions that protect a multitude of interest". 53

Dalam tindak pidana lingkungan, berkaitan erat dengan konsep kerugian dan kerusakan nyata (actual harm) dan ancaman kerusakan (threatened harm). Sebab harus dipahami bahwa kerugian atau kerusakan dalam tindak pidana lingkungan seringkali tidak terjadi seketika atau dapat dikuantifikasi dengan mudah. Dengan demikian ada kategori korban yang bersifat konkrit dan ada korban yang bersifat abstrak. Disinilah pembicaraan sering bersinggungan dengan tindak pidana formil dan tindak pidana materiil; tindak pidana spesifik dan tindak pidana generik. Masalahnya perbuatan seseorang tidak hanya "causes impairment of the quality of the natural environment", tetapi juga "is likely to cause impairment of the quality of the natural environment". 54

\footnotetext{
${ }^{51}$ G. DrupsteendanC.J. Kleijs Wijnnobel, Upaya Penegakan..., Op. Cit., hlm. 20.

${ }^{52}$ Ibid., hlm. 21.

${ }^{53}$ Muladi, Demokratisasi..., Op. Cit., hlm. 97.

${ }^{54}$ Ibid., hlm. 99.
} 
Dalam pembahasan RUU KUHP, tindak pidana lingkungan hidup juga diusahakan diatur secara proporsional. Dalam hal ini dibedakan secara tajam antara: 1. membiarkan pengaturan dalam hukum administratif apa yang dinamakan tindak pidana yang bersifat "administrative dependence of environmental criminal law", baik yang merupakan delik formil (abstract endangerment) maupun delik materiil (concrete endangerment); 2. memasukkan dalam kodifikasi hukum pidana (KUHP): a) independent crime apply to serious pollution if a concrete danger to human life or health exist; b) independent crime apply even if no ecological harm or danger exist, if abstract endangerment to human life or health exist; c) concrete endangerment of the environment (penalizing unlawful emissions) as independent crime, although administrative licence will still have a justificative effect. 55

Tindak pidana lingkungan adalah perintah dan larangan undang-undang kepada subjek hukum yang jika dilanggar diancam dengan penjatuhan sanksi pidana, dengan tujuan untuk melindungi lingkungan hidup secara keseluruhan ataupun unsur-unsur dalam lingkungan hidup seperti hutan satwa, lahan, udara, dan air, serta manusia. Oleh karena itu, dengan pengertian ini, tindak pidana lingkungan hidup tidak hanya ketentuan-ketentuan pidana yang dirumuskan dalam UU No. 32 Tahun 2009 tentang PPLH, tetapi juga ketentuan-ketentuan pidana yang dirumuskan dalam peraturan perundang-undangan lain sepanjang rumusan ketentuan itu ditujukan untuk melindungi lingkungan hidup secara keseluruhan atau bagian-bagiannya. ${ }^{56}$

Oleh karena itu, beberapa UU yang terkait dengan pengelolaan sumber daya alam ataupun yang langsung terkait dengan pelestarian alam dan lingkungan hidup perlu direvisi, seperti antara lain UU 22 Tahun 2001 tentang Minyak dan Gas Bumi dan UU No. 4 Tahun 2009 tentang Pertambangan Mineral dan Batubara. Kedua UU ini memuat ketentuan pidana antara lain mengenai penambangan atau eksplorasi tanpa ijin; survey umum tanpa hak eksplorasi dan/atau eksploitasi tanpa mempunyai Kontrak Kerja Sama; pengolahan, pengangkutan, penyimpanan tanpa ijin, dan sebagainya. Namun UU ini tidak memuat bagaimana dengan kelalaian ataupun kesengajaan dari kegiatan

\footnotetext{
${ }^{55}$ Muladi, Beberapa Catatan Dalam RUU KUHP, dalam Lembaga Studi dan Advokasi Masyarakat (ELSAM), Beberapa Tulisan Terkait Kebijakan Kriminal Dalam RUU KUHP, ELSAM, Jakarta, 2006, hlm. 15.

56 Takdir Rahmadi, Hukum Lingkungan di Indonesia, Rajawali Pers, Jakarta, 2014, hlm. 221.
} 
pertambangan minyak dan gas bumi ataupun dari kegiatan pertambangan mineral dan batu bara yang dapat mengakibatkan pencemaran atau kerusakan lingkungan hidup.

\section{Penutup}

Permasalahan lingkungan hidup berupa pencemaran dan kerusakan lingkungan sudah semakin kompleks dan cenderung sulit untuk tertangani dengan baik, indikasi ini terlihat dengan semakin menurunnya kualitas lingkungan hidup. Dampak negatif dari penurunan kualitas lingkungan hidup adalah timbulnya ancaman atau dampak negatif terhadap kesehatan, menurunnya nilai estetika, kerugian ekonomi (economic cost), dan terganggunya sistem alami (natural system). Permasalahan lingkungan hidup, apabila dikaitkan dengan masalah hak-hak asasi manusia, tidak saja merupakan persoalan negara per negara, tetapi juga menjadi persoalan regional bahkan internasional (antar bangsa). Hak untuk memperoleh lingkungan hidup yang sehat merupakan salah satu hak asasi yang diatur dalam Universal Declaration of Human Right, 1948 (Art. 25) jo Art.11 International Convenant on Economic, Social and Cultural Rights (1966). Hak untuk mendapatkan lingkungan hidup yang baik dan sehat juga ditegaskan dalam Pasal 28 H Undang-Undang Dasar Negara Republik Indonesia Tahun 1945.

Upaya preventif dalam rangka pengendalian dampak lingkungan hidup perlu dilaksanakan dengan mendayagunakan secara maksimal instrumen pengawasan dan perizinan. Namun dalam hal pencemaran dan kerusakan lingkungan hidup sudah terjadi, perlu dilakukan upaya represif berupa penegakan hukum pidana guna menjamin kepastian hukum sebagai landasan bagi perlindungan dan pengelolaan sumber daya alam serta kegiatan pembangunan lain.

Penegakan hukum pidana dalam permasalahan lingkungan hidup yaitu dengan tetap memperhatikan asas ultimum remedium sebagai upaya terakhir setelah penerapan penegakan hukum administratif dan/atau hukum perdata sudah tidak layak lagi untuk dipertahankan. Permasalahan lingkungan hidup berupa pencemaran dan perusakan lingkungan hidup merupakan perbuatan 
yang secara langsung atau tidak langsung dapat membahayakan kehidupan dan jiwa manusia. Hukum pidana pada dasarnya bertujuan untuk melindungi jiwa dan kehormatan manusia dan harta benda. Ketika pencemaran dan perusakan lingkungan hidup telah menimbulkan dampak negatif terhadap kehidupan dan jiwa manusia, maka perbuatan tersebut harus dipandang sebagai perbuatan yang bertentangan dengan moral dan layak untuk dikenakan sanksi pidana.

Oleh karena itu, beberapa peraturan perundang-undangan yang terkait dengan pengelolaan sumber daya alam ataupun yang langsung terkait dengan pelestarian alam dan lingkungan hidup perlu direvisi. Revisi perlu dilakukan tidak hanya karena perbuatan pencemaran dan perusakan lingkungan bertentangan dengan moral melainkan juga karena mengikuti perkembangan internasional yang menghendaki agar fungsi hukum pidana dalam tindak pidana lingkungan menjadi primum remedium bukan lagi ultimum remedium. Penggunaan hukum pidana adalah dalam rangka perlindungan terhadap lingkungan hidup baik dalam lingkup internasional, regional, maupun domestik.

\section{Daftar Pustaka}

\section{Buku:}

Alvi, Syahrin, Beberapa Isu Hukum Lingkungan Kepidanaan, Sofmedia, Jakarta, 2009. Arief,Barda Nawawi, Beberapa Aspek Kebijakan Penegakan dan Pengembangan Hukum Pidana, Citra Aditya Bakti, Bandung, 1998.

Duff, R.A. and David Garland, A Reader on Punishment, University Press, Oxford, 1994.

Faure, J.C. Oudijk, D.D. Schaffmeister, Kekhawatiran Masa Kini. Pemikiran Mengenai Hukum Pidana Lingkungan Dalam Teori dan Praktek, Citra Aditya Bakti, Bandung, 1994.

Hamzah, Andi, Penegakan Hukum Lingkungan, Sinar Grafika, Jakarta, 2008.

Husin, Sukanda, Penegakan Hukum Lingkungan Indonesia, Sinar Grafika, Jakarta, 2009.

Lamintang, P.A.F., Dasar-Dasar Hukum Pidana Indonesia, Citra Aditya Bakti, Bandung, 1997.

Muladi, Demokratisasi, Hak Asasi Manusia, dan Reformasi Hukum di Indonesia, The Habibie Center, Jakarta, 2002. 
Packer, Herbert L., The Limit of The Criminal Sanction, Stanford University Press, California, 1968.

Prodjodikoro, Wirjono, Tindak-Tindak Pidana Tertentu di Indonesia, Refika Aditama, Bandung, 2002.

Rahmadi, Takdir, Hukum Lingkungan di Indonesia, RajaGrafindo Persada, Jakarta, 2014.

Rangkuti, Sri Sundari,Hukum Lingkungan dan Kebijaksanaan Lingkungan Nasional, Airlangga University Pers, Surabaya, 2000.

Remmelink,Jan,Hukum Pidana. Komentar Atas Pasal-Pasal Terpenting dari Kitab Undang-Undang Hukum Pidana Belanda dan Padanannya dalam Kitab UndangUndang Hukum Pidana, Gramedia Pustaka Utama, Jakarta, 2003.

Soekanto, Soerjono dan Sri Mamudji, Penelitian Hukum Normatif, Cetakan ketujuh, PT Raja Grafindo Persada, Jakarta, 2003.

Sudarto, Hukum dan Hukum Pidana, Alumni, Bandung, 2007.

Sunggono, Bambang, Metodologi Penelitian Hukum (Suatu Pengantar), RajaGrafindo Persada, Jakarta, 1997.

Walker, Nigel,Sentencing in a rational Society, Allen Lane The Penguin Press, London, 1969.

Wignjosoebroto, Soetandyo, Hukum, Paradigma, Metode, dan Dinamika Masalahnya, Lembaga Studi dan Advokasi Masyarakat (ELSAM) dan perkumpulan untuk Pembaruan Hukum Berbasis Masyarakat dan Ekologi (HuMa), Jakarta, 2002.

\section{Jurnal}

Bawono, Bambang Tri, dan Anis Mashdurohatun, "Penegakan Hukum Pidana Di Bidang Illegal Logging Bagi Kelestarian Lingkungan Hidup Dan Upaya Penanggulangannya", Jurnal Hukum Vol. XXVI, No. 2, Agustus 2011.

\section{Makalah}

Muladi, Beberapa Catatan Dalam RUU KUHP, dalam Lembaga Studi dan Advokasi Masyarakat (ELSAM), Beberapa Tulisan Terkait Kebijakan Kriminal Dalam RUU KUHP, Jakarta: ELSAM, 2006.

Prosiding "Seminar Pemikiran Perubahan UU No. 23 Tahun 1997 tentang Pengelolaan Lingkungan Hidup", Kementerian Lingkungan Hidup, Jakarta: Hotel Indonesia, 15 Desember 2003.

\section{Risalah dan Peraturan Perundang-undangan}

Indonesia, UU No. 5 Tahun 1960 tentang Pokok-Pokok Agraria (UU PA).

Indonesia, UU No. 11 Tahun 1974 tentang Pengairan. 
Indonesia, UU No. 5 Tahun 1990 tentang Konservasi Sumber Daya Alam Hayati dan Ekosistemnya.

Indonesia, UU No. 41 Tahun 1999 tentang Kehutanan.

Indonesia, UU No. 22 Tahun 2001 tentang Minyak dan Gas Bumi.

Indonesia, Perpu No. 1 Tahun 2004 tentang Perubahan Atas UU No. 41 Tahun 1999 tentang Kehutanan.

Indonesia, UU No. 4 Tahun 2009 tentang Pertambangan Mineral dan Batubara.

Indonesia, UU No. 12 Tahun 2011 tentang Pembentukan Peraturan PerundangUndangan.

Indonesia, UU No. 18 Tahun 2013 tentang Pencegahan dan Pemberantasan Perusakan Hutan.

Indonesia, UU No. 39 Tahun 2014 tentang Perkebunan. 